\title{
ГЕНЕТИКА
}

GENETICS

\section{Essentially pure partial trisomy 6(p21.31-p25) (case report and literature review)}

\author{
Odalis Molina-Gamboa $^{1}{ }^{\mathbb{D}}$, Anduriña Barrios-Martínez ${ }^{1}{ }^{1}$, \\ Alina García-García ${ }^{2}{ }^{\mathbb{D}}$, Luanda Maceira ${ }^{1}{ }^{\mathbb{D}}$, Luis A. Méndez-Rosado ${ }^{1}$ \\ ${ }^{1}$ National Center of Medical Genetics, \\ 31 Ave., Havana, 11300, Cuba \\ ${ }^{2}$ William Soler Pediatric Hospital, \\ 100 Ave., Havana, 10300, Cuba \\ Corresponding author: Luis A. Méndez-Rosado (albermen@infomed.sld.cu)
}

\begin{abstract}
Background: In reviewed literature, several patients with duplication or partial trisomy of the $6 \mathrm{p}$ region have been described. Most of these cases are associated with a partial monosomy of another chromosome. It has been suggested that partial trisomy $6 p$ constitutes a well-defined syndrome. The aim of the study: To achieve a better clinical delineation of the $6 \mathrm{p}$ syndrome through the description of a patient with partial trisomy 6(p21.31-p25) comparing his characteristics with international reports and to discuss aspects of the phenotype of this syndrome. Materials and methods: A detailed clinical analysis of the patient's condition was performed. The chromosomes were studied through the GTG-banding analysis. Results: On clinical examination we observed: a small anterior fontanel; fine, sparse and very pale hair, almost white hair; very white, translucent and thin skin; pale and sparse eyebrows and eyelashes; very narrow palpebral fissures with palpebral ptosis (blepharophimosis); a high nasal bridge, and straight nose with tiny nostrils; low implantation of the ears; microcephaly, neurodevelopmental and psychomotor delay; long philtrum, thin lips, the upper lip almost inverted and the mouth is small. From the neurological point of view there was evidence of trunk hypotonia and limb hypertonia. These are all typical features of trisomy $6 p$ syndrome. A cytogenetic study of the patient and his father showed that trisomy $6 p$ was due to an adjacent segregation I in paternal gametogenesis as the father is a 6,16-translocation carrier. Conclusion: The possible critical region is difficult to determine due to the clinical heterogeneity present in this syndrome. However, this case should be analyzed by molecular methods to determine more precisely the extent of the area involved in the trisomy.
\end{abstract}

Keywords: trisomy 6p; translocation; neurodevelopmental disorders; craniosynostosis; syndrome

Acknowledgements: The authors want to recognize the support of the RFBR and CITMA institutions of Russia and Cuba respectively for our study. 
For citation: Molina-Gamboa O, Barrios-Martínez A, García-García A, et al. Essentially pure partial trisomy 6(p21.31-p25) (case report and literature review). Research Results in Biomedicine. 2021;7(4): 322-329. DOI: 10.18413/2658-65332021-7-4-0-1

Introduction. Several patients with duplication or partial trisomy of the $6 \mathrm{p}$ region have been described in consulted literature. Most cases were associated with a partial monosomy of another chromosome (product of an adverse segregation due to a translocation), so it has been suggested that partial trisomy $6 p$ constitutes a well-defined syndrome [1-4]. When this trisomy appears in association with a partial monosomy of another chromosome, it is difficult to fully define whether the clinical features observed are actually due to trisomy $6 \mathrm{p}$ or to haploinsufficiency of the genes involved in the partial monosomy of a particular chromosome involved in the translocation. There are reports of this syndrome with a different extension of the trisomic segment on the short arm of chromosome 6 , which also makes it difficult to determine exactly whether the clinical manifestations are due to a large clinical heterogeneity of the disease or to the different genes involved in partial trisomy [5]. Among the affections usually reported in partial trisomy $6 p$ we can find a neurodevelopmental and psychomotor delay and other anomalies, such as severe or moderate dysmorphic features, low-set ears, prominent forehead, blepharophimosis, choanal atresia, arched palate, craniosynostosis, thin lips and tiny nostrils. Other findings have also reported cardiac defects, palpebral ptosis, intellectual disability, feeding problems, immunodeficiency, renal anomalies and pigmentary skin anomalies [1-11]. The current paper presents a partial trisomy $6 \mathrm{p} 21.3-6 \mathrm{p} 25$ product of a $6 ; 16$ translocation, with the peculiarity that in chromosome 16 only the telomeric region (16q24) is involved, which implies that a possible monosomy of this region in the propositus does not represent a relevant clinical repercussion. Based on the particularities of this rearrangement, with an essentially pure trisomy $6 \mathrm{p}$, we discuss the clinical features of the patient and compare it with a review of the literature in order to achieve a better clinical deline- ation of this syndrome and to discuss aspects of its phenotype.

Materials and methods. Karyotyping was performed using lymphocyte culture without exogenous serum and GTG bands at a resolution of 550 bands, according to standard laborato ry techniques. The working algorithm described in [12] was applied. The software Metasystem was used for image capture, processing and analysis. Images were obtained by bright-field microscopy (Olympus BX-51).

Results and discussion. The patient is a 5-year-old boy, with non-consanguineous parents (a 22-year-old mother and a 27-yearold father), referred from the William Soler pediatric hospital. The proband showed a family history of mother in remission of Hodgkin's lymphoma, who concluded the treatment 4 and a half years before becoming pregnant, and maternal grandmother who died of cervical cancer. The child was born preterm at 36 weeks, by physiological delivery, with a weight of $1870 \mathrm{~g}$ (less than the 5th percentile), supine length $44.5 \mathrm{~cm}$ (less than the 5 th percentile) and head circumference $30.5 \mathrm{~cm}$. The fetus was assessed as symmetrical intrauterine growth retarded. In the neonatology service, abdominal and transfontanel ultrasound and echocardiogram did not show visceral congenital defects.

Physical examination by a genetics specialist at 2 months of age showed: a small anterior fontanel; thin, sparse and very pale hair, almost white; very white, translucent and thin skin; pale and sparse eyebrows and eyelashes. Very narrow palpebral fissures with palpebral ptosis (blepharophimosis), a high nasal bridge, a straight nose with tiny nostrils, low implantation of the ears, long philtrum, thin lips, the upper lip almost inverted and the mouth is small. In the thorax teletelia is detected. In the hands and feet there were deep palmar and plantar folds. From the neurological point of view there was evidence of trunk hypotonia and limb hypertonia. 
Follow-up of the patient revealed the presence of other disorders such as gastroesophageal reflux, irritability, neurodevelopmental and growth retardation and microcephaly. Neuroimaging studies of brain structures showed signs of brain atrophy, predominantly left temporal.

At the present moment, the child is 5 years old and has presented some changes in the phenotype, he maintains short stature and similar facial features, but the hair has taken a reddish and tarnished appearance, with a thicker and rougher consistency. From the psychomotor point of view, the delay in the acquisition of skills persists and, fundamentally, a significant speech proficiency delay. Hearing loss has been ruled out as a cause of this disability.

\section{Cytogenetic analysis}

Fifteen metaphases were observed under the bright-field microscope and at least 5 karyotypes were analyzed.

The 15 metaphases showed a male karyotype with an apparent addition on the long arm of chromosome 16 in all metaphases studied: 46, XY, add, (16), (q23) (Figure 1).

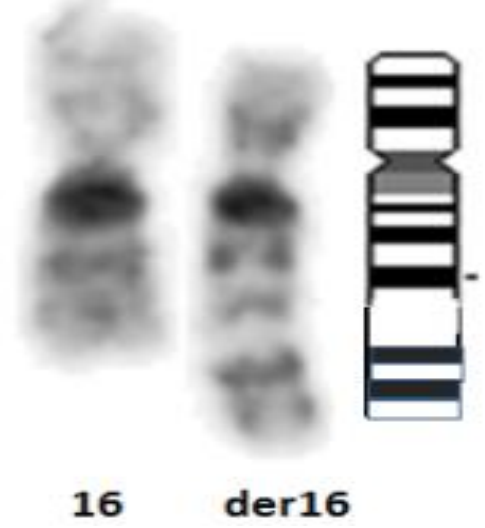

Fig. 1. Partial karyotype showing chromosomes 16. Depicted on the right, the $16 \mathrm{q}$ with the apparent addition, shown at the idiogram.

To determine the inherited or de novo possible origin of this rearrangement, a chromosomal study of the parents was indicated. The father was found to carry a translocation between the short arm of chromosome 6 and the long arm of chromosome 16, as shown in Figure 2.
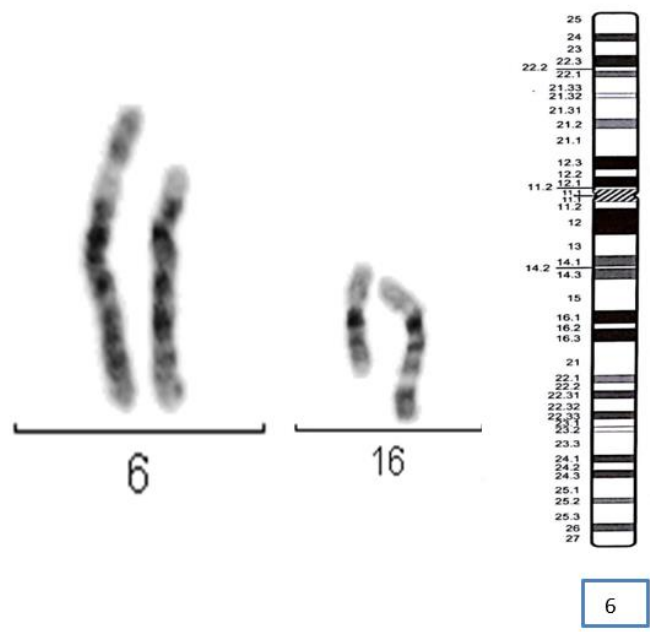
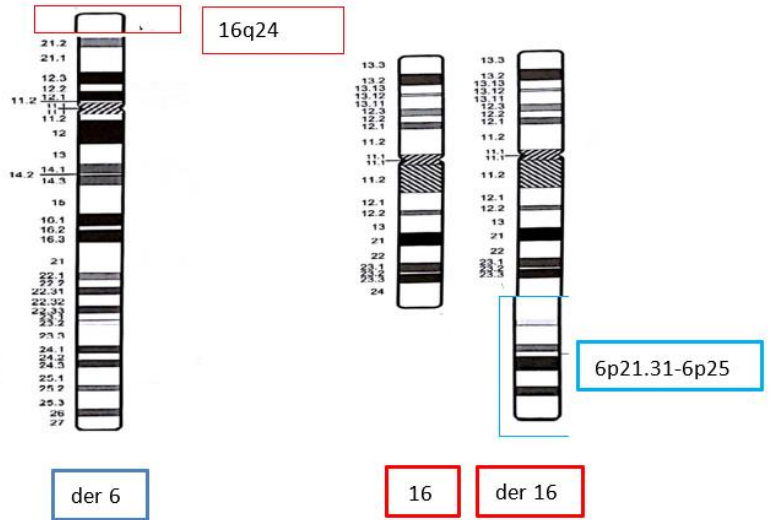

$\operatorname{der} 6$ der 16

Fig. 2. Partial karyotype of the paternal translocation 6;16 and representation of the translocation in the ideogram

Taking into account the result of the cytogenetic study of the parents it is concluded that the child presents a derivative 16, product of a translocation $(6,16)$ of paternal origin; his karyotype would be:

46, XY, der (16) t $(6,16)$ (p21.31, q24) pat Karyotype: 46, XY, t $(6,16)$, (p21.31, q24). Chromosomal analysis of the mother showed a normal 46, XX karyotype.

The short arm of chromosome 6 has 1 204 genes making it difficult to estimate the contribution of gene expression to the trisomy $6 p$ phenotype. [13] The diversity of phenotypic features that patients with the partial trisomy $6 p$ 
may present should be considered. However, unusual facial features, a developmental delay, a prominent forehead, microcephaly, blepharophimosis and palpebral ptosis, [1-11] can also be found in other patients with completely different chromosomal rearrangements. Furthermore, if we contemplate that not all patients with trisomy $6 \mathrm{p}$ present all the phenotypic features described above, it becomes difficult to consolidate a phenotypic pattern that characterizes trisomy $6 \mathrm{p}$ as a syndrome.

The case described in this report presents a partial trisomy involving the 6p21.31p25 region and the clinical features most commonly reported in the syndrome are summarized in Table 1 . The theoretical analysis of the region with partial trisomy $6 \mathrm{p}$ allows us to point out which genes may be responsible for the clinical features of the patient hereby described. The craniofacial alterations link to the BMP6 gene (6p24.3) has been suggested by Castiglione et al. 2013 $[13,14]$.

The bone morphogenetic proteins (BMPs) are a family of secreted signaling molecules that can induce ectopic bone growth. Many BMPs are part of the transforming growth factor- $\beta$ superfamily $[15,16]$.

A triple dose of this gene could be responsible for malformations such as craniosynostosis, choanal atresia and other more moderate cranial malformations. This gene is within the region implicated in the partial trisomy $6 \mathrm{p}$ of the described patient, however, neither choanal atresia nor craniosynostosis are observed in this patient. Similar situations are reported in the literature by several authors. Refer to Table 1.

As suggested by Varvagiannis et al, 2013 [17] craniosynostosis is caused by a triple dosage of the RUNX2 gene (6p21.1). The RUNX2 gene (RUNX family Transcription factor 2) is a member of the RUNX family of genes that are essential for osteoblastic differentiation and skeletal morphogenesis. RUNX2, also known as CBFA1, maps to 6p21 and encodes the RUNT-related transcription factor 2, a master regulator of osteoblast differentiation. Our cytogenetic analysis of the patient under study excludes the $6 \mathrm{p} 21.1$ region. In addition, molecular methods were not used in our analysis of the rearrangement breakpoints. The clinical description of this patient does not report craniosynostosis, which suggests that the RUNX2 gene is outside of the partial trisomy region despite the relative proximity to the breakpoint (6p21.31) involved in the translocation $[6,16]$. Villa et al. hypothesized that duplication of the gene for bone morphogenetic protein 5 (BMP5) might be responsible for the premature fusion of the patient's sagittal sutures, but this gene is located at $6 \mathrm{p} 12.1$ completely outside the trisomy $6 p$ region of the proband.

Regarding the ocular anomalies present in the reported case (blepharophimosis, palpebral ptosis, epicanthal folds) $\mathrm{Su}$ and collaborators (2012) [18] suggested nine genes that could be involved in these anomalies: FOXQ1(6p25.3), FOXF2(6p25.3), FOXC1(6p25.3), NRN1(6p25.1), EDN1(6p24.1), ATXN1(6p22.3), DEK (6p22.3), E2F3(6p22.3) and NRSN1(6p22.3). The FOX genes have also been considered by other authors to be responsible for the ocular malformations in these syndromes [19]. For example, the FOXC1 gene plays a fundamental role in the regulation of embryonic and ocular development; mutations in this gene could cause different types of glaucoma and iris dysgenesis [13].

In a general sense many of the phenotypic characteristics of patients with partial trisomy at $6 \mathrm{p}$ are attributable to the $6 \mathrm{p} 25-\mathrm{p} 21$ region; among them: pre- and postnatal growth retardation, microcephaly, a prominent forehead, ocular malformations, low ear implantation, long philtrum, hypoplastic kidneys, congenital heart defects, recurrent infectious episodes [15]. 
Table

\section{Clinical signs of trisomy $6 p$}

\begin{tabular}{|c|c|c|c|c|c|c|c|c|c|c|c|}
\hline $\begin{array}{l}\text { Clinical } \\
\text { findings }\end{array}$ & $\begin{array}{c}\text { Villa } \\
\text { et al. } \\
2007 \\
6 \text { p10p } \\
22.1\end{array}$ & $\begin{array}{c}\text { Petko } \\
\text { vich et } \\
\text { al. } \\
2003 \\
\text { 6p11.1 } \\
\text { p25 } \\
\end{array}$ & $\begin{array}{c}\text { Fogu et } \\
\text { al. 2007 } \\
\text { 6p12.1p } \\
22.1\end{array}$ & $\begin{array}{c}\text { Varvagl } \\
\text { ianis et } \\
\text { al. 2013 } \\
\text { 6p12.3- } \\
\text { p21.1 }\end{array}$ & $\begin{array}{c}\text { Breun } \\
\text { ing et } \\
\text { al. } \\
1977 \\
6 p 21 p \\
25 \\
\end{array}$ & $\begin{array}{c}\text { Castigl } \\
\text { ioni et } \\
\text { al. } \\
2013 \\
6 p 23- \\
25.3 \\
\end{array}$ & $\begin{array}{c}\text { Pierpo } \\
\text { n et al } \\
2000 . \\
6 \text { p21.3 } \\
\text { p25 }\end{array}$ & $\begin{array}{c}\text { Giard } \\
\text { ino et } \\
\text { al. } \\
2002 \\
6 p 22 p \\
25 \\
\end{array}$ & $\begin{array}{c}\text { Roth- } \\
\text { lisbenger } \\
\text { et al. } \\
1999 \\
6 \text { 23p25 }\end{array}$ & $\begin{array}{c}\text { Sivasan- } \\
\text { karan } \\
\text { et al. } \\
2016 \\
6 p 22.3 p 2 \\
5 \\
\end{array}$ & $\begin{array}{c}\text { Pre- } \\
\text { sent } \\
\text { case } \\
6 \text { p21.3 } \\
\text { p25 }\end{array}$ \\
\hline $\begin{array}{l}\text { Develop- } \\
\text { mental de- } \\
\text { lay, Mental } \\
\text { retardation }\end{array}$ & $\mathrm{x}$ & $\mathrm{x}$ & $\mathrm{x}$ & $\mathrm{x}$ & $\mathrm{x}$ & - & $\mathrm{x}$ & $\mathrm{x}$ & $\mathrm{x}$ & $\mathrm{x}$ & $\mathrm{x}$ \\
\hline $\begin{array}{l}\text { Craneofa- } \\
\text { cial } \\
\text { Abnormali- } \\
\text { ties * }\end{array}$ & $\mathrm{x}$ & $\mathrm{X}$ & $\mathrm{x}$ & $\mathrm{x}$ & $\mathrm{x}$ & $\mathrm{x}$ & $\mathrm{x}$ & $\mathrm{x}$ & $\mathrm{x}$ & $\mathrm{x}$ & $\mathrm{x}$ \\
\hline $\begin{array}{l}\text { Cranio- } \\
\text { synostosis }\end{array}$ & $\mathrm{x}$ & $\mathrm{X}$ & - & $\mathrm{x}$ & - & $\mathrm{x}$ & - & - & - & - & - \\
\hline $\begin{array}{l}\text { Cardiac } \\
\text { defects }\end{array}$ & & & & - & $\mathrm{X}$ & $\mathrm{x}$ & & & & & \\
\hline $\begin{array}{l}\text { Low birth } \\
\text { weight }\end{array}$ & & & & $\mathrm{x}$ & $\mathrm{x}$ & $\mathrm{x}$ & $\mathrm{x}$ & $\mathrm{x}$ & $\mathrm{x}$ & $\mathrm{X}$ & $\mathrm{x}$ \\
\hline $\begin{array}{l}\text { Feeding } \\
\text { problems }\end{array}$ & & $\mathrm{X}$ & $\mathrm{x}$ & & $\mathrm{x}$ & & $\mathrm{x}$ & $\mathrm{X}$ & & $\mathrm{x}$ & $\mathrm{x}$ \\
\hline $\begin{array}{l}\text { Immunode- } \\
\text { ficiency }\end{array}$ & & & & $\mathrm{x}$ & $\mathrm{x}$ & & $\mathrm{x}$ & $\mathrm{x}$ & & & \\
\hline $\begin{array}{l}\text { Renal } \\
\text { anomalies }\end{array}$ & & & & & $\mathrm{x}$ & $\mathrm{x}$ & & $\mathrm{x}$ & & & \\
\hline $\begin{array}{l}\text { Skin pig- } \\
\text { mentary } \\
\text { anomalies }\end{array}$ & $\mathrm{x}$ & & $\mathrm{x}$ & - & $\mathrm{x}$ & & & $\mathrm{x}$ & $\mathrm{x}$ & & $\mathrm{x}$ \\
\hline $\begin{array}{l}\text { Psychomo- } \\
\text { tor delay } \\
\text { and other } \\
\text { neurological } \\
\text { disorders }\end{array}$ & $\mathrm{x}$ & & $\mathrm{x}$ & $\mathrm{x}$ & $\mathrm{x}$ & - & & $\mathrm{x}$ & $\mathrm{x}$ & $\mathrm{x}$ & $\mathrm{x}$ \\
\hline
\end{tabular}

Note: * Craneofacial Abnormalities, included: High prominent forehead, Flat occipitum, Choanal atresia, Micrognathia, Low-set ears, High arched, Small mouth or thin lips, Blepharophimosis, Tiny nares, Short nose. Excluded: Craniosynostosis

Many of these conditions are present in the reported case and coincidentally the region with trisomy 6p21.31-p25 encompasses the region described previously in the propositus.

The patient has a moderate mental disability, a frequent characteristic of trisomy $6 p$, even though in some cases the mental disability is mild and allows normal social interaction [7, 20, 21]. The most remarkable affection in this patient is the speech proficiency delay at 5 years of age. Polymorphisms and CNVs (copy number variations) in several of the genes within the 6p21.3-6pter region (ATXN1， DTNBP1， JAR1D2， LYRM4, MYLIP, NQO2, NRN1, RREB1, RIPK1, SERPINB1) have been reported to be implicated in intellectual disability [21-31].
As previously mentioned, one of the limitations of present study is that the chromosomes breakpoints were not determined by molecular methods. Regarding the q24 breakpoint on chromosome 16 and based on the child's clinical findings we found no phenotypic alterations corresponding to a possible monosomy of $16 \mathrm{q} 24.1$ or $16 \mathrm{q} 24.3$, the most likely sites to be involved in the rearrangement. Monosomy at 16q24.3 is associated with seizures and autism spectrum, brain abnormalities and neonatal thrombocytopenia. Monosomy at $16 q 24.1$, on the other hand, is associated with lethal lung disease, with refractory pulmonary hypertension and the child dies in the first months of life $[32,33]$. None of these alterations corresponds to the clinical findings of the 
proband. It follows that the part of chromosome $16 \mathrm{q}$ involved in the 6,16 translocation is the telomere of chromosome 16, a highly repetitive, non-coding region of DNA.

In a general sense, this can be considered an essentially pure 6p21.31-p25 trisomy, because the found monosomy suggests a noncoding region on chromosome 16. All the clinical features reported in the patient correspond to trisomy of the 6p25-p21.31 region. Other authors consider that genes located between $6 \mathrm{p} 25.1$ and $6 \mathrm{p} 25.2$ are responsible for the clinical features of this trisomy, ${ }^{13}$ which is not consisting with our finding. Villa et al. report a case with typical features of the syndrome in which band 6p25 trisomy is not involved [8].

The careful clinical delineation of the patient combined with the chromosomal findings and the international literature reports suggest that the critical region fundamental to this syndrome cannot only be circumscribed to $6 \mathrm{p} 25$, as it is probably more extensive. However, this case should be analyzed by molecular methods to determine more precisely the extent of the area involved in the trisomy. In addition, a detailed molecular characterization of the genes in this region and their function during the ontogeny of these patients affected with this trisomy is necessary, because some of the features of this syndrome, such as heart disease and renal anomalies, are not present in the proband. On the other hand, triple dose genes, BMP6, do not always affect the phenotype of individuals with trisomy $6 p$ in the same way, which could suggest a variable expressiveness of this gene in the clinic of this syndrome.

\section{Financial support}

No financial support has been provided for this work.

\section{Conflict of interests}

The authors have no conflict of interest to declare.

\section{References}

1. Therkelsen AJ, Klinge T, Henningsen $\mathrm{K}$, et al. A family with a presumptive C-F translo- cation in five generations. Annals of Genetics. 1971;14:13-21.

2. Petković I, Barisić I, Bastić M, et al. Paternal origin of $\operatorname{der}(\mathrm{X}) \mathrm{t}(\mathrm{X} ; 6)$ in a girl with trisomy $6 \mathrm{p}$ and unbalanced $\mathrm{t}(6 ; 10)$ mosaicism in her mother. American Journal of Medical Genetics, Part A. 2003;120A(2):266-71. DOI: https://doi.org/10.1002/ajmg.a.20017

3. Breuning MH, Bijlsma JB, de France HF. Partial trisomy $6 \mathrm{p}$ due to familial translocation $\mathrm{t}(6 ; 20)(\mathrm{p} 21 ; \mathrm{p} 13)$. A new syndrome? Human Genetics. $\quad 1977 ; 38(1): 7-13$. DOI: https://doi.org/10.1007/BF00295802

4. Berner AL, Bağci $\mathrm{S}$, Wohlleber $\mathrm{E}$, et al. Familial translocation $\mathrm{t}(6 ; 20)(\mathrm{p} 21 ; \mathrm{p} 13)$ resulting in partial trisomy $6 \mathrm{p}$ and partial monosomy 20p: report of a new case and review of the literature. Cytogenetic and Genome Research. 2012;136(4):308-13. DOI: https://doi.org/10.1159/000337019

5. Sivasankarana A, Murthyc K, Orugantic VP. De-novo 'pure' partial trisomy (6)(p22.3 $\rightarrow$ pter): a case report and review of the literature. Clinical Dysmorphology. 2016;26(1):26-32. DOI: https://doi.org/10.1097/MCD.0000000000000160

6. Fogu G, Bandiera P, Cambosu F, et al. Pure partial trisomy of $6 \mathrm{p} 12.1-\mathrm{p} 22.1$ secondary to a familial 12/6 insertion in two malformed babies. European Journal of Medical Genetics. 2007;50(2):103-11. DOI: https://doi.org/10.1016/j.ejmg.2006.11.002

7. Pierpont MEM, Hentges AS, Gears LJ, et al. Unbalanced 4;6 translocation and progressive renal disease. American Journal of Medical Genetics. 2000;95(3):275-80. DOI: https://doi.org/10.1002/10968628(20001127)95:3<275::AID-

AJMG15>3.0.CO;2-X

8. Villa O, Del Campo M, Salido M, et al. Small supernumerary marker chromosome causing partial trisomy $6 \mathrm{p}$ in a child with craniosynostosis. American Journal of Medical Genetics, Part A. 2007;143A:1108-1113. DOI: https://doi.org/10.1002/ajmg.a.31709

9. Giardino D, Finelli P, Caufin D, et al. Pure 6 p22 $\rightarrow$ pter trisomic patient: refined FISH characterization and genotype-phenotype correlation. American Journal of Medical Genetics. 2002;108(1):36-40.

DOI: https://doi.org/10.1002/ajmg.10225

10. Barøy T, Misceo D, Strømme P, et al. Haploinsufficiency of two histone modifier genes on 6p22.3, ATXN1 and JARID2, is associated with intellectual disability. Orphanet Journal of 
Rare Diseases. 2013;8:3. DOI: https://doi.org/10.1186/1750-1172-8-3

11. Kuipers BCW, Vulto-van Silfhout AT, Marcelis C, et al. Two patients with intellectual disability, overlapping facial features, and overlapping deletions in 6p25.1p24.3. Clinical Dysmorphology. 2013;22(1):18-21. DOI: https://doi.org/10.1097/MCD.0b013e32835b6e39

12. Méndez-Rosado LA, García D, Molina-Gamboa $\mathrm{O}$, et al. Algorithm for the diagnosis of patients with neurodevelopmental disorders and suspicion of a genetic syndrome. Archivos Argentinos de Pediatria. 2020;118(1):47-60. DOI: http://dx.doi.org/10.5546/aap.2020.eng.52

13. Castiglione A, Guaran V, Astolfi L, et al. Karyotype-Phenotype Correlation in Partial Trisomies of the Short Arm of Chromosome 6: A Family Case Report and Review of the Literature. Cytogenetic and Genome Research. 2013;141:243-259. DOI: https://doi.org/10.1159/000353846

14. Chen CP, Chen M, Chen CY, et al. Prenatal diagnosis and molecular cytogenetic characterization of de novo pure partial trisomy $6 \mathrm{p}$ associated with microcephaly, craniosynostosis and abnormal maternal serum biochemistry. Gene. 2014;536(2):425-9.

DOI: https://doi.org/10.1016/j.gene.2013.12.036

15. Schinzel A. Catalogue of Unbalanced Chromosome Aberrations in Man, 2nd edition. Berlin: Walter de Gruyter GmbH \& Co KG; 2001.

16. Mueller TD, Nickel J. Promiscuity and specificity in BMP receptor activation. FEBS Letters. 2012;586(14):1846-1859. DOI: https://doi.org/10.1016/j.febslet.2012.02.043

17. Varvagiannis K, Stefanidou A, Gyftodimou Y, et al. Pure de novo partial trisomy $6 \mathrm{p}$ in a girl with craniosynostosis. American Journal of Medical Genetics, Part A. 2013;161A:343351. DOI: https://doi.org/10.1002/ajmg.a.35727

18. Su P-H, Lee I-C, Yang S-F, et al. Nine genes that may contribute to partial trisomy $(6)($ p22 $\rightarrow$ pter $)$ and unique presentation of persistent hyperplastic primary vitreous with retinal detachment. American Journal of Medical Genetics, Part A. 2012;158A:707-712. DOI: https://doi.org/10.1002/ajmg.a.33943

19. Mataftsi A, Islam L, Kelberman D, et al. Chromosome abnormalities and the genetics of congenital corneal opacification. Molecular Vision. 2011;17:1624-1640.

20. Delatycki MB, Voullaire L, Francis D, et al. Directly inherited partial trisomy of chromosome $6 \mathrm{p}$ identified in a father and daughter by chromosome microdissection. Journal of Medical
Genetics. $\quad 1999 ; 36: 335-338$.

DOI: http://dx.doi.org/10.1136/jmg.36.4.335

21. Röthlisberger B, Kotzot D, Gnehm $\mathrm{HE}$, et al. 'Essentially pure' partial trisomy $(6)($ p23 $\rightarrow$ pter $)$ in two brothers due to maternal $\mathrm{t}(6 ; 17)(\mathrm{p} 23 ; \mathrm{p} 13.3)$. American Journal of Medical Genetics, Part A. 1999;85(4):389-394. DOI: https://doi.org/10.1002/(SICI)1096-

8628(19990806)85:4<389::AID-

AJMG16>3.0.CO;2-A

22. Burdick KE, Lencz T, Funke B, et al. Genetic variation in DTNBP1 influences general cognitive ability. Human Molecular Genetics. 2006;15(10):1563-1568.

DOI: https://doi.org/10.1093/hmg/ddi481

23. Chandler D, Dragović M, Cooper M, et al. Impact of Neuritin 1 (NRN1) polymorphisms on fluid intelligence in schizophrenia. American Journal of Medical Genetics, Part B: Neuropsychiatric Genetics. 2010;153B(2):428437. DOI: https://doi.org/10.1002/ajmg.b.30996

24. Di Benedetto D, Di Vita G, Romano C, et al. 6 p22.3 deletion: report of a patient with autism, severe intellectual disability and electroencephalographic anomalies Molecular Cytogenetics. 2013;6:4. DOI: https://doi.org/10.1186/17558166-6-4

25. Melani M, Simpson KJ, Brugge JS, et al. Regulation of cell adhesion and collective cell migration by hindsight and its human homolog RREB1. Current Biology. 2008;18(7):532-537. DOI: https://doi.org/10.1016/j.cub.2008.03.024

26. Payton A, Miyajima F, Ollier W, et al. Investigation of a functional quinine oxidoreductase (NQO2) polymorphism and cognitive decline. Neurobiology of Aging. 2010;31(2):351-352. DOI:

https://doi.org/10.1016/j.neurobiolaging.2008.04.0 14

27. Ramos-Quiroga JA, Sánchez-Mora C, Casas M, et al. Genome-wide copy number variation analysis in adult attention-deficit and hyperactivity disorder. Journal of Psychiatric Research. 2014;49:60-67.

DOI: https://doi.org/10.1016/j.jpsychires.2013.10.022

28. Romaniello R, Arrigoni F, Bassi MT, et al. Mutations in $\alpha$ - and $\beta$-tubulin encoding genes: implications in brain malformations. Brain and Development. 2015;37(3):273-280. DOI: https://doi.org/10.1016/j.braindev.2014.06.002

29. Rizzi TS, Arias-Vasquez A, Rommelse $\mathrm{N}$, et al. The ATXN1 and TRIM31 genes are related to intelligence in an ADHD background: evidence from a large collaborative study totaling 
4,963 subjects. American Journal of Medical Genetics, Part B: Neuropsychiatric Genetics. 2011;156:145-157.

DOI: https://doi.org/10.1002/ajmg.b.31149

30. Zhang JP, Burdick KE, Lencz T, et al. Meta-analysis of genetic variation in DTNBP1 and general cognitive ability. Biological Psychiatry. 2010;68(12):1126-1133. DOI: https://doi.org/10.1016/j.biopsych.2010.09.016

31. Barøy T, Misceo D, Strømme P, et al. Haploinsufficiency of two histone modifier genes on 6p22.3, ATXN1 and JARID2, is associated with intellectual disability. Orphanet Journal of Rare Diseases. 2013;8:3. DOI: https://doi.org/10.1186/1750-1172-8-3

32. Orphanet [Internet]. Sindrome de microdelecion 16q24.3. 2021 [cited 2021 Jul 8]. Available from: https://www.orpha.net/ consor/cgi-bin/OC disease -search- simple.php? Ing $=\mathrm{ES}$

33. Orphanet [Internet]. Sindrome de microdelecion 16q24.1. 2021 [cited 2021 Jul 8]. Available from: https://www.orpha.net/ consor/cgi-bin/disease - search- simple.php? Ing=ES

Received 22 June 2021

Revised 30 July 2021

Accepted 7 September 2021
Information about the authors

Odalis Molina-Gamboa, Degree in Biology, Graduate in Cytogenetic Clinical Laboratory, National Center of Medical Genetics, Havana, Cuba, E-mail: odalismg@cngm.sld.cu, ORCID: https://orcid.org/0000-0003-1151-3509.

Anduriña Barrios-Martínez, Master in Medical Genetics, Assistant Researcher, Assistant Professor at the Cytogenetic Laboratory, National Center of Medical Genetics, Havana, Cuba, E-mail: abarrios@cngm.sld.cu, ORCID: https://orcid.org/0000-0002-5957-3538.

Alina García-García, MD, Clinical Geneticist at the Genetics Department, William Soler Pediatric Hospital, Havana, Cuba, E-mail: alinagg@infomed.sld.cu, $\quad$ ORCID: https://orcid.org/0000-0002-2642-3090.

Luanda Maceira, Graduate in Cytogenetic Clinical Laboratory, National Center of Medical Genetics, Havana, Cuba, E-mail: lmrosales@cngen.sld.cu, ORCID: https://orcid.org/0000-0001-6487-1882.

Luis A. Méndez-Rosado, PhD, Master in Medical Genetics, Full Professor, Researcher at the Cytogenetics Laboratory, National Center of Medical Genetics, Havana, Cuba, E-mail: albermen@infomed.sld.cu, ORCID: https://orcid.org/0000-0002-4401-0054. 